

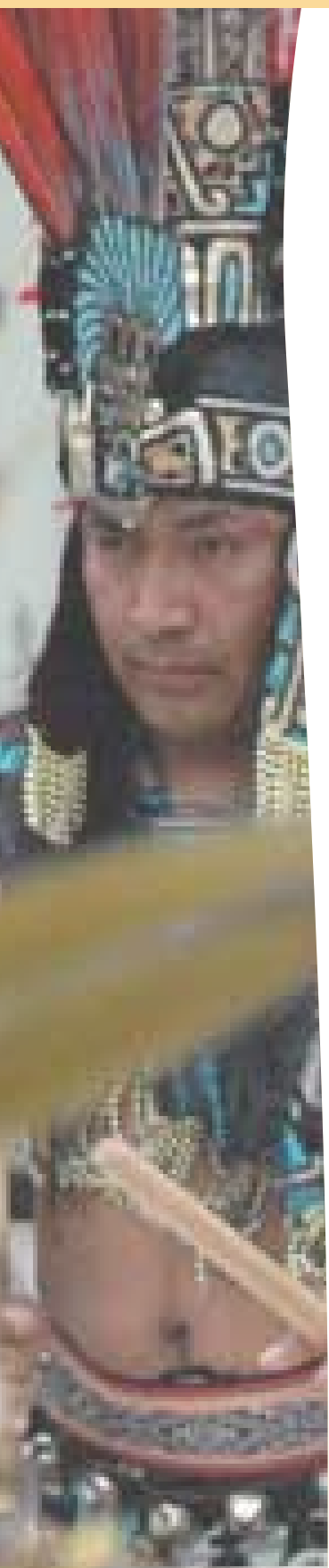

\section{Effective Strategies}

When planning a 4-H Bloco Drum and Dance Program, it is important to look at all aspects of effectively operating and administering the program. Having a stable, permanent staff is the most critical factor for creating and maintaining the program's culture and climate, but it is also essential that you have a staff that shares a common vision and relates well to young people. Hiring adults who support and teach young people about their academic, social, emotional, and physical development in the 4-H Drum and Dance after-school setting is the key to a successful program. The Site Director accomplishes this objective by providing a range of activities and strategies that the program uses to build the competencies of the staff and volunteers: the ability of staff and volunteers to apply a specific set of skills and knowledge to their day-to-day practice. Additionally, the Site Director takes care of evaluation and is responsible for the careful allocation of available resources. This publication highlights key components and focuses on issues or concerns that relate specifically to administering middle and high school programs for youth aged 12 to 18 .

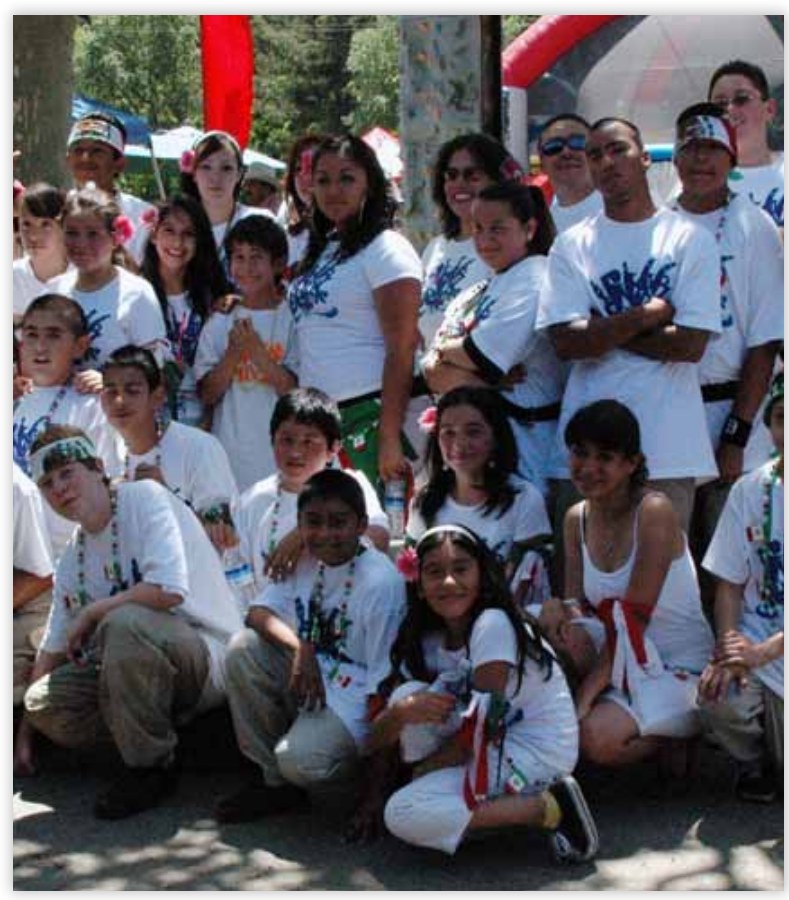

\section{Management of the Program}

You can avoid many conflicts and much confusion if you start out by setting clear policies and program directions. Effective behavior management ensures a positive and safe environment for all youth, according to Raley, Grossman, and Walker, authors of Getting It Right (2005).

Instructors can establish simple ground rules at the start of activities to set a tone for mutual respect. The way instructors treat youth is also critical. If instructors respect youth and model the behavior they expect from youth, the youth will respond in kind. For those behavior challenges that inevitably arise despite the best efforts at prevention, having established program rules with consequences will help ensure consistency across instructors and promote a sense of fairness among participants. A good instructor can deal with behavior challenges quickly and move on with instruction. This program management approach permits even the more-difficult youth to have multiple fresh starts. Here are some key policies and practices to keep in mind as you develop your Bloco Drum and Dance program:

- Set rules of conduct before you begin the program, basing them on the 4-H Code of Conduct.

- Follow school and 4-H policies.

- Create standard procedures for Bloco Drum and Dance program staff and participants to follow. This includes providing employees with contracts and developing job descriptions for volunteer parents and teens. Review job descriptions with all relevant parties.

- Justify and validate the reasons for all policies and procedures and make sure that everyone has a clear understanding of the role of each policy in the program.

- Be consistent in following the policies and procedures.

- Develop a framework for changing and updating polices and procedures so the group 


\section{7. \\ - Policies should be set by the 4-H Bloco Advisory Committee with input from staff, volunteers, and participants. \\ - Write down the program's policies and procedures and make sure everyone in the program receives a copy.}

\section{Staffing}

Programs that invest carefully in recruiting and screening new job candidates stand a better chance of retaining staff members. Staff should be experienced both in youth development and in the art of

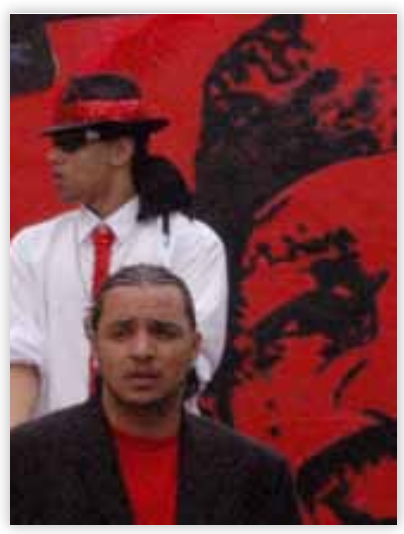

Brazilian dance or drum. A team approach to interviewing and screening new job candidates may also promote stability because the candidates recommended for hire will more likely fit in with the team. Developing an effective and efficient process for identifying staffing needs as well as for recruiting competent, caring, and qualified staff should be a major priority for any 4-H Bloco Drum and Dance after-school program.

Effective staff management begins with written job descriptions, which help ensure an equitable division of labor and clear performance expectations. Whenever possible, good management also means aligning staff members' interests and skills with the new tasks they are assigned. Less-experienced staff may welcome new responsibilities that enhance their skills. Each site may serve as many as 50 youth. If the number of teens is greater than 40 , volunteer adults who are 25 years of age and older may serve in assistant staff roles. 4-H policies require one adult per 10 participating youth (see Appendix for job descriptions and salaries).
The paid staff members of the 4-H Bloco Drum and Dance after-school program are key to a successful program. The following positions are needed:

- Program Coordinator (at each school site)

- Site Director

- Lead Percussionist (Drum) Instructor

- Assistant Drum Instructor

- Batteria (Dance) Instructor

- Assistant Dance Instructor

- Food Demonstration and Snack Coordinator 4-H Bloco Drum and Dance staff often have to serve as administrators, supervisors, teachers, custodians, secretaries, bookkeepers, negotiators, or mentors, or in other capacities for the teens in their care. These jobs are often not easy, as not every class can be offered the best physical room situation. The program may often have to share space with other groups, transform a multi-purpose room into an effective new environment, and then move to another room on another day or even to an outside area. The 4-H Bloco Drum and Dance program must be able to change to meet the challenges of creating an atmosphere of fun and excitement for teens. Staff members are often asked to perform all of these functions with limited budgets and, sometimes, with inadequate resources.

\section{Program Coordinator}

The Program Coordinator should have the ability to work well with a wide and varied group of people and to coordinate many tasks. The 4-H Bloco Program Coordinator should have good communication and organizational abilities, effective management skills, and excellent delegation skills. This person's role is to serve as the liaison between other agencies and groups and the site staff. He or she reports directly to the Advisory Committee and supervises the Site Director. 


\section{Site Director}

The Site Director should have the ability to

- supervise instructors and volunteers

- follow policies and procedures

- complete paperwork and bookkeeping

- make sound decisions (based on training and experience) in case of emergencies

- help with curriculum design and implementation

- interact with the Advisory Committee, school representatives, and participants' parents in a positive manner

- keep all parties informed

\section{Instructors}

The Instructors should

- have the performance and musical ability necessary to teach Brazilian drum or dance

- be able to provide effective, non-punitive guidance and concern for each individual teen as well as for the group

- understand the developmental needs of teens

- be a positive role model for teens

- communicate well with teens

- enjoy working with teens

- carry out their duties with enthusiasm, flexibility, and punctuality

- be willing to share the limelight with others

- work well with volunteers

- be able to make good decisions

\section{Food Demonstration and Snack Coordinator}

An organized, structured, and supervised 4-H Drum and Dance program that provides snacks will allow teens to think and behave better, and that helps them to do better in and out of school. After-school snack time helps to ensure that teens receive the nutrition they need in order to learn, play, and grow.
The Food Demonstration and Snack Coordinator provides and organizes healthy snacks before each practice. The Coordinator plans and implements the purchase or snacks, supplies, and drinks, and arranges for set-up and take-down of tables, cleanup, and proper storage of food leftovers prior to the start of drum and dance practice.

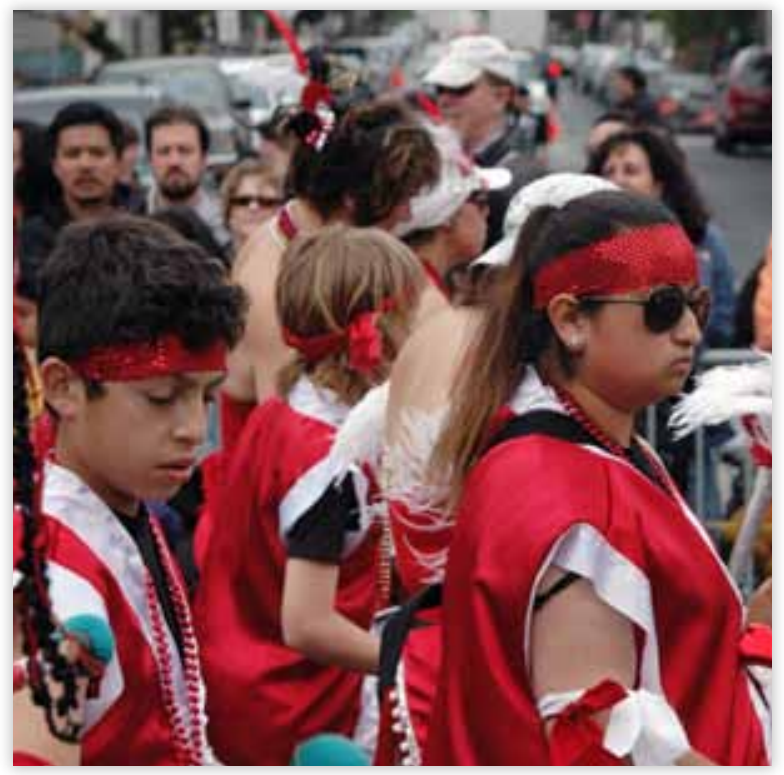

\section{Program Operations}

\section{Hours of Operation}

If your program operates more than 3 days a week in California, it has to be licensed by the state as an ongoing program. Make sure to check the state requirements before you begin your program. Setting the hours of operation is an important decision. The planning committee must decide

- how many days a week the program will operate

- how long the after-school classes will be held

- how many weeks the program will operate

Most 4-H Bloco Drum and Dance programs operate for 36 weeks during the school year. Make a calendar available to all participants listing the days and times each week when the drum and dance classes will be offered. Be sure to account for minimum days, in-service days, and school holidays in your program. 


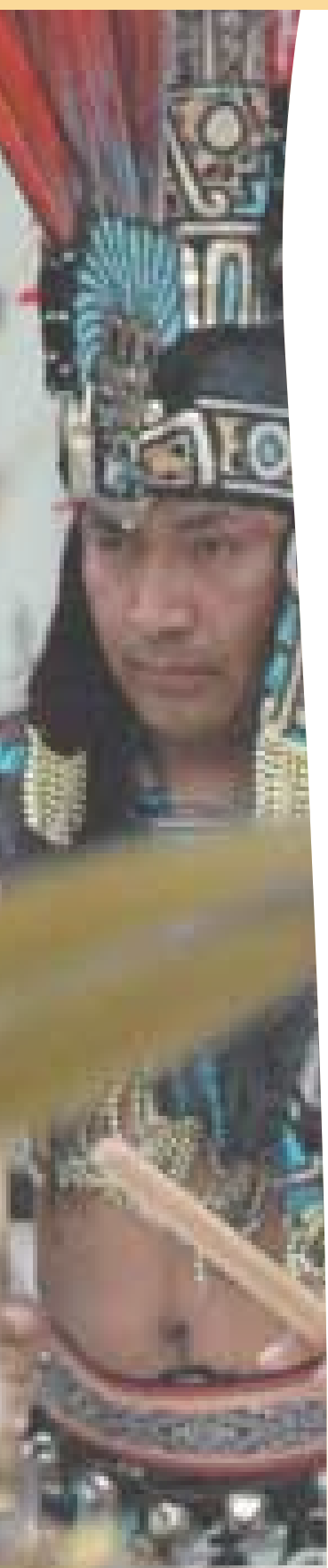

The 4-H Bloco program offers a two-day-aweek program for 36 weeks of the school year. As youth advance in the program, they may be eligible to take a third class for advanced members who want to become teen leaders and mentors for the younger teens. By scheduling drum and dance classes to follow regularly scheduled school hours, the program enables the teens to go directly to the classes, in many cases without leaving the school grounds. In some areas, parents can arrange for pick-up at the end of the drum or dance class by securing late bus drop-off. With permission from parents or guardians, students may also walk home if it is a reasonable walking distance. Older teens may have access to a car they can use to get home. Bear in mind that California 4-H policy explicitly states that "members under the age of 18 may not drive other members on 4-H business at any time." Staff members need to make sure they have a clear understanding of how the teens will be departing and getting home.

If the 4-H Drum and Dance Program increases to five days a week, you may have to get the program licensed through appropriate state and county agencies. Contact your state licensing agency and the U.S. Department of Health and Human Services for licensing requirements (http://nccic.acf.hhs.gov/afterschool/ childcareregs.pdf). State requirements may dictate how many staff members must be on site at any given time, and those requirements may be different from the 4-H requirements. If the state or county agency requires fewer on-site staff than are required by 4-H, however, you still need to follow the 4-H requirements. You may have to ask adult volunteers to help with supervision if you do not have enough paid staff.

\section{Recruitment and Hiring}

Before you can begin to recruit and hire, you first need to determine the employees' work schedule, what type of activities they will be conducting, and what time of day they will offer those activities.

Follow these steps:

- Put together a job description and application (see Appendix for job descriptions and salaries).

- Determine the salary.

- Develop a contract. (If you are working through a government employment agency, you will need to get the contract approved before you advertise the position.)

- Develop a staff recruitment flyer.

- Advertise the position online and in the newspaper, with groups at school, businesses, and other contacts in your community.

- Schedule interviews.

\section{Hiring Staff}

Hiring is a perennial process even for top afterschool programs, according to Raley, Grossman, and Walker's Getting It Right (2005). After developing an overall plan you should select the number of instructors you will need. At the same time, you should determine how many adult volunteers will be required to meet the program needs.

Salaries for staff vary according to experience. Recruitment of a qualified candidate pool is the first step in hiring staff. If you invest the right amount of time in carefully recruiting and screening new job candidates, you will give the program a better chance of retaining staff members in the long run. Staff members who have passion, respect, and concrete skills for working with young people and who have dance and drum experience are the strongest fit for your after-school program. Young people are most likely to connect with staff members like this, and the staff members will be more likely to find the work rewarding enough to make them want 


Creating a curriculum and managing dance and
drum activities in a class become much more
complicated when teen social interactions, age
differences, and varying degrees of experience
with music come into play.
It is very important that instructors in the
program to be appropriately matched to their
teen group. Most people who teach or work
successfully with teens have developed skills for
reaching this group of youth. The communication
style, teaching approach, and curriculum content
that are effective for elementary school youth
are very different from those that work well for
teenagers. This is one reason we limit the Bloco
Drum and Dance program to junior high and high
school youth only.

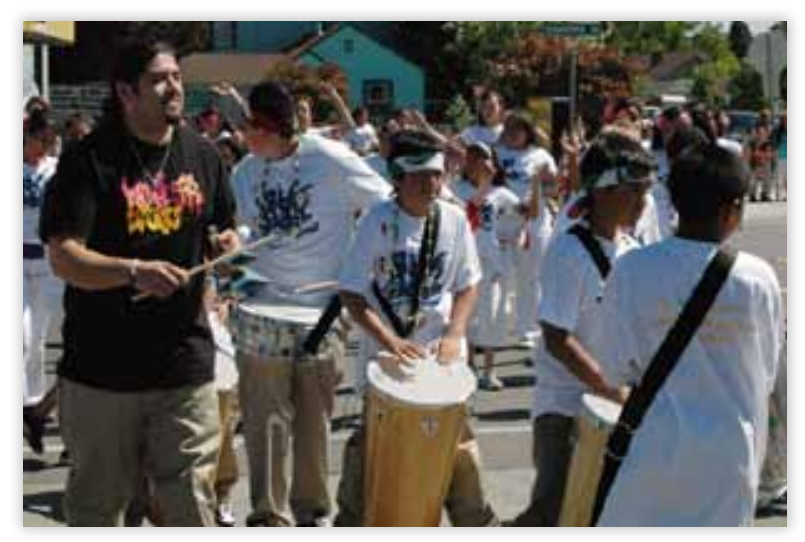

\section{Being an Effective Instructor/Teacher}

Here are some tips for a becoming a successful instructor or teacher in the 4-H Bloco Drum and Dance Program:

- Be interested and attentive. Teens can tell whether they have your interest and attention from your actions, words, and behavior.

- Encourage communication. Some teens need to be encouraged to express their feelings and need to have others validate the importance of what they have to say.

- Listen. Be attentive to what the teens are saying. Encourage discussion.

- Active listening. This is a proven, important skill for helping teens communicate with each other and with adults in the program. In active listening, you re-state in your own words what the teen has just shared. This has the effect of helping the teens clarify what they have to say as they relate experiences to you and to the group. One of the best skills for a teacher is to be a good listener.

- Look for nonverbal messages. Many teens communicate messages nonverbally through tone of voice, body language, changes in behaviors, and facial expressions. A teacher is better able to tell how youths are doing in a drum or dance class if he or she pays attention not only to what the youths say with words but also what they say through their actions, through nonverbal messages.

\section{Additional Management Considerations}

Here are some important things to consider when managing the program.

\section{Supply Requests}

Any request for supplies should be put on a written request form and submitted two weeks ahead of time to the Program Coordinator. You should also keep a small emergency fund for small requests that may need a shorter turn-around time. Receipts are acceptable for reimbursement, so long as the Program Coordinator has given prior approval for the purchase. All reimbursement requests must be accompanied by receipts. Sample forms are in the Appendix.

\section{Enrollment}

The 4-H Bloco Drum and Dance Program, like all 4-H activities in California, is part of University of California Cooperative Extension. The 4-H Program requires that all teens, volunteer parents, and paid staff complete the appropriate enrollment process and requires that all paid staff and volunteer adults be fingerprinted. 


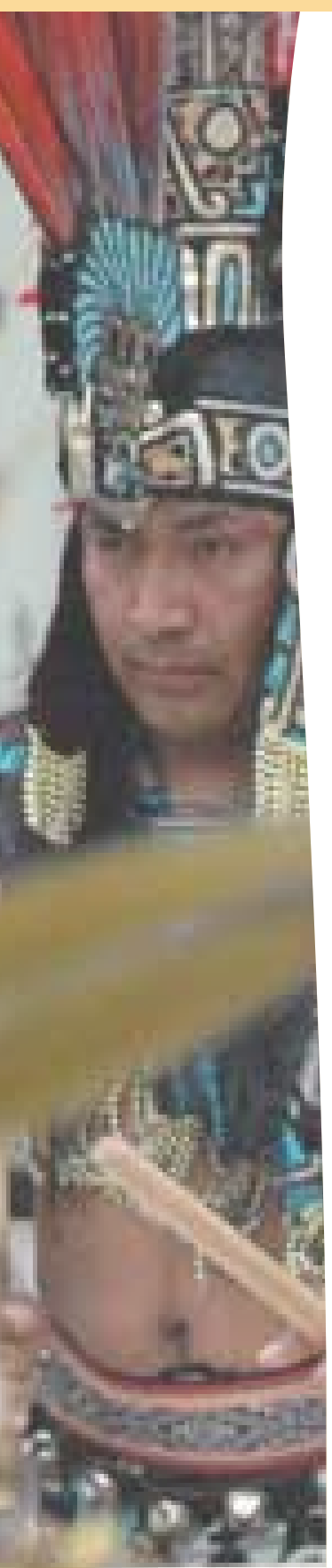

Full enrollment information can be accessed online at www.ca4h.org/join/enrollment. Teen members must be enrolled as 4-H members and must participate two to three times a week in either the drum class or the dance class. Some Bloco Drum and Dance Program groups require an additional fee to help cover expenses, usually paid at 8-week intervals. Other groups have grant funding and may not require a fee. Check with your local Site Director to find out about fees at your location.

All participants are required to complete the enrollment process in accordance with their state and local county requirements. The final number of youth enrolled in the program will determine how many paid and volunteer staff will be needed to operate the program effectively (see Appendix).

\section{Parent Orientation}

Effective parent orientation is key to the success of the program. Outlining the program to parents and asking them for assistance is also crucial. Developing a parent handbook is a good way to alleviate confusion and possible disputes with parents while at the same time giving them an idea of what the program activities will be for the year. You will want to include activity dates, fundraising opportunities, volunteer adult positions available within the program, and additional support for paid staff (see Appendix for parent orientation handouts).

\section{Written Reports}

Short written reports should be sent to the parents on a regular basis. Consider sharing information on

- Daily attendance of participants

- Prep time activities

- Special program needs

- Behavioral problems

- Musical equipment needs

- Funding

- Relationship with the school or community site

\section{Site Management}

The 4-H Bloco Drum and Dance Program will probably use borrowed space at school facilities after regular school hours. Good communication between 4-H Bloco staff, the 4-H Program, and the school district is vital to a well-run program. Written forms and agreements are essential, especially since there will be contract employees working on the site. Make sure each employee has an approved contract. Check with the University of California or other lead agency or school staff for hiring requirements.

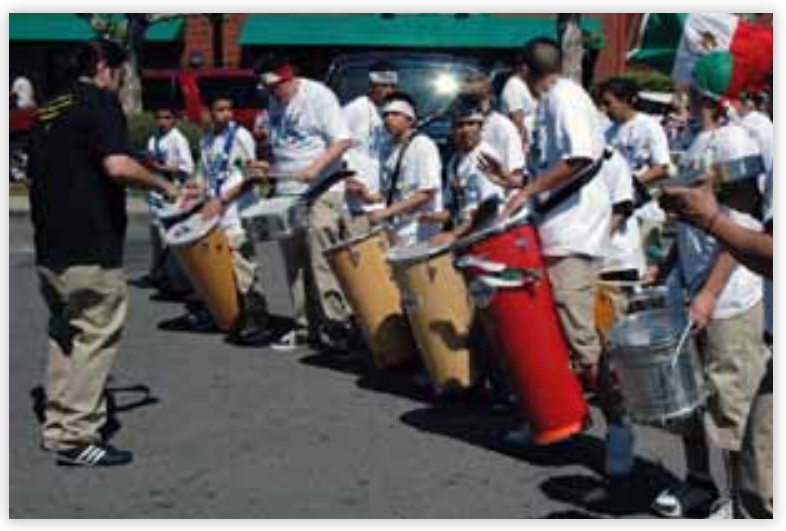

\section{Trainings}

You can expand staff skills either through training or a review of the program. While state licensing requirements often mandate training in $\mathrm{CPR}$, first aid, and child-abuse prevention, research has found that training in teen development, curriculum planning, and group management are most valuable for enhancing the daily work of instructors. When interviewing staff, Program Directors tend to look for training in fundraising, management, and building collaborations with other partners.

There are two challenges when you conduct a training: paying for the training and scheduling time for the training sessions. To reduce costs, 4-H Bloco directors can look to large organizations such as partnering agencies and ask them to include program staff in their own training sessions. The Sonoma County 4-H Bloco Drum and Dance Program scheduled trainings by setting aside a paid staff in-service training day three times a year. 


Activity Monitoring
The Program Coordinator and 4-H Bloco Advisory
Committee will be monitoring different activities
throughout the year to assess quality of the
program. Monitoring activities could include
parent and teen surveys, one-on-one interviews
with staff and parents, or observation of activity
sessions. Each of these methods can be a
valuable resource in evaluation the program (see
Developing and Implementing an Evaluation Plan,
publication 8437, for evaluation guidelines).

\section{Working with Volunteers}

Volunteer workers can be a wonderful addition to your program. In many cases, parents or key adults in the community can serve as volunteers. When you make the decision to use volunteers, be sure to take care of the following:

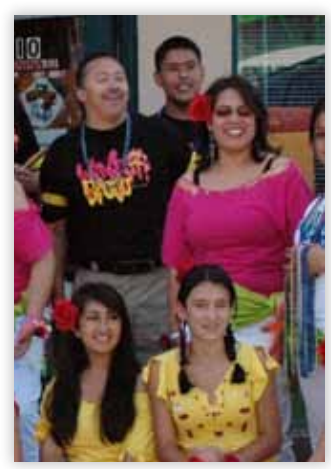

- Develop job descriptions. Be clear and specific. Include time lines and job responsibilities, and match the personality to the position. (See sample job descriptions in the Appendix.)

- Consider the needs of both the program and the volunteer.

- Make sure to recognize each volunteer at the end of the program for his or her contributions. Recognition can take a number of forms, such as a gift, a letter to the volunteer's employer, or public recognition by the teens.

- Plan to evaluate the volunteer's work. You can do this with one-on-one interviews along with written comments and regular feedback.

If a volunteer does not perform his or her role successfully, give him or her an opportunity to leave with dignity.

\section{Why Do People Volunteer?}

According to the Sonoma County Volunteer Center, people volunteer for the following reasons:

- Their friends do.

- It's fun.

- They have a passion, or a cause they care about.

- It looks good on a résumé.

- They hope it will lead to a job.

- They want to meet people with whom they have something in common.

- They want to find out about a new community.

- They feel guilty if they don't volunteer.

- It is the right thing to do.

- They (or someone they know) got help from the group.

- They have to, because of school, court, or some other reason.

- It is convenient.

- It is easier to say yes than to say no.

\section{What Keeps People from Volunteering?}

- Fear of the unknown.

- "I have no time ..."

- Scheduling problems.

- Some nonprofits can be hard to volunteer for.

- Their skills don't meet the group's needs.

- No perceived need.

- They don't know how to get started.

- No one has asked them to volunteer.

\section{Recruitment Tips for Volunteers}

Consider the following items when you are recruiting for volunteers for the 4-H Drum and Dance Program.

- Assess the 4-H Drum and Dance Program's needs.

- Is the job appropriate for a volunteer?

- Develop a job description (see Appendix for format). What skills will your volunteer need in order to complete the job? 
- Target your recruitment based on the skills that the program is looking for.

- What do you need for them to say "Yes!"?

- If the volunteer is going to solicit donated food for snacks, it is imperative that it be healthy food.

- Show that you appreciate your volunteers.

\section{Writing Volunteer Position Descriptions}

When designing a volunteer position description, keep the program goals in mind. It is important to outline the work that the volunteer will need to do. The job description is an important tool for the recruitment of volunteers in the 4-H Drum and Dance Program as it highlights the skills needed to perform the tasks.

Design the Bloco Drum and Dance volunteer position description along these lines (see Appendix for additional information on job descriptions):

- Position Title: Give the position a specific, descriptive title that gives the volunteer a sense of identity and helps the salaried staff and other volunteers understand the assigned role.

- Work Location: Indicate where the 4-H Bloco volunteer will be working. Will the volunteer be working at the program site or at home? Is public transportation available, or does the volunteer need a car?

- Volunteer Impact: Describe the purpose of the 4-H Bloco Drum and Dance Program and tell how the volunteer's work will impact the program's outcome and clients.

- Qualifications: Be clear and concise. List the qualifications required for the position. Include education, personal characteristics, skills, abilities, and experience required.

- Time Commitment: Be sure to include the length of service required for the position. Include hours, days per week, starting and ending dates, and any other special considerations. Include a date for initial training.

- 4-H Bloco Advisory Committee: In order for this program to be successful, it is important to find volunteers who will serve on the Advisory Committee. (See Developing Positive Relationships, publication 8430, for job description.) This committee is made up of community stakeholders, often prominent individuals within the community, parents, youth, and staff.

\section{Working with Teens in Groups}

4-H Bloco Drum and

Dance activities are most effective if they are planned in a way that allows each member to proceed at his or her own pace and includes teens in a common planning process. Few experiences are more difficult for a conscientious instructor than to prepare

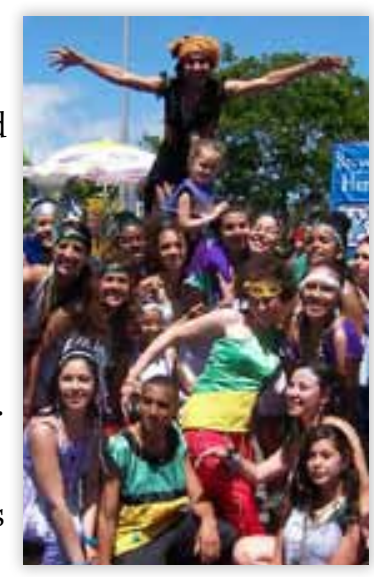
a carefully planned drum and dance project and have it fail because the group members are apathetic or say it is "boring." Involvement of teens in the planning process is critical to the success of the activities. Teens develop important skills in planning, arbitration, compromise, communication, and consideration when they assume responsibility for planning the activities in which they will participate.

Allow for some choices. Although teens may not be able to make choices about every aspect of the program, the instructor and volunteer may want to take suggestions for field trip ideas and ask teens to decide on some of the performance dates and places. Teens do not always respond enthusiastically when adults assign them tasks, even though this may often appear to an adult to be the most efficient way of getting something done, but you have to keep in mind that one of the program goals is to encourage teens to develop their leadership skills. Drum and dance activities that are chosen jointly by the leader and the teens will form the foundation for a meaningful group experience. 


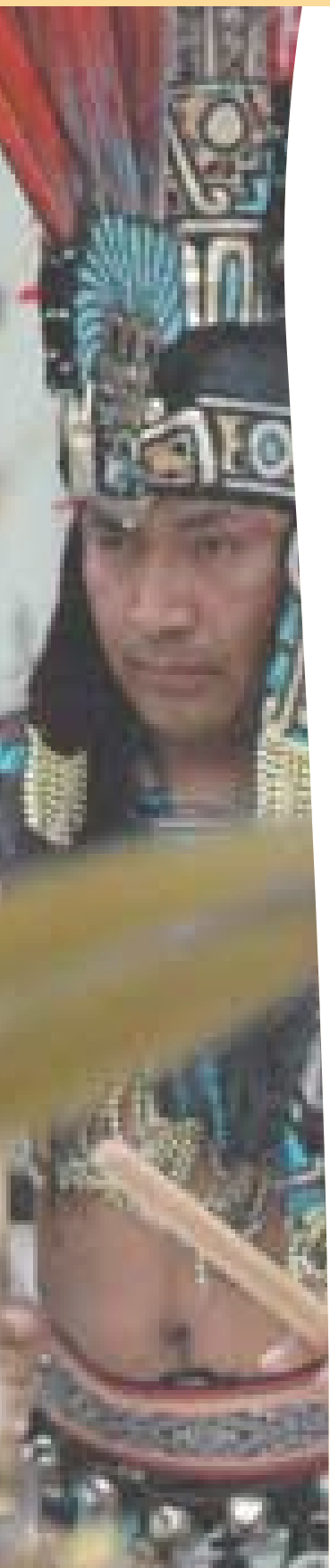

$1+4$

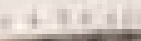

\section{Working with Teen Leaders/Mentors}

Adult instructors and volunteers should seek out and encourage older teens in the program who might want to become involved in leadership roles. First you can help the teen develop a plan, then you can give him or her training and guidance in carrying out the plan, and then you can help him or her evaluate the results (see www.ca4h.org to find more information for teen leaders). The objectives the youth outlines in his or her plan need not be rigid.

\section{Who Are Teen Leaders/Mentors?}

Teen leaders/mentors are participants who learn leadership skills by leading and helping others. Teens can add even more to the program if you encourage them to take on leadership roles. Teen leaders/mentors are expected to help teach and supervise the drum and dance groups as well as assist with activities and events.

To keep teen leaders interested and active, you may want to increase their responsibilities as they gain in experience and skills. Submit a plan of work for the teen based on the needs of the after-school group. The plan should be prepared in consultation with and approved by the adult leader, instructor, organization, or Project Director. A plan of work may include recruiting, orienting, and encouraging teens to participate in the program, assisting the leader/instructor in a class or project, or helping to plan and carry out an event.

Here are some specific leadership activities that can be part of a teen's plan:

- Helping with classes by demonstrating drum and dance techniques to other teen members.

- Developing a newsletter.

- Sending out practice notices.

- Helping with larger events, such as performances and presentations by groups of participants.

- Managing some of the 4-H Drum and Dance administrative tasks, such as helping participants complete enrollment and registration forms.

- Sitting on the Advisory Committee that oversees the program.

Note: When a teen leader/mentor works with a group of younger members, an adult leader must be present in order to satisfy the requirements of the University of California's liability insurance.

\section{Building a Team}

According to the California After-School Management Manual and Curriculum manual (1986), a team can be defined as "a group of persons, each a unique individual, who collectively choose to use the abilities that each person brings to accomplish a larger purpose that all of them have chosen." The life of the team is characterized by cooperation. Team members need to set goals and define roles together. Team members also share the tasks that enable them to carry out their plans. A team builds on the strengths of each of its members.

Individuals choose to become part of the team because they share common values and concerns. An effective team will build on personal strengths and utilize personal differences to develop new ways to accomplish a task. Effective teams are made up of teens, staff, volunteers, and parents. If you want to have a successful 4-H Drum and Dance Program, the first step is to build an effective team made up of paid staff and volunteers.

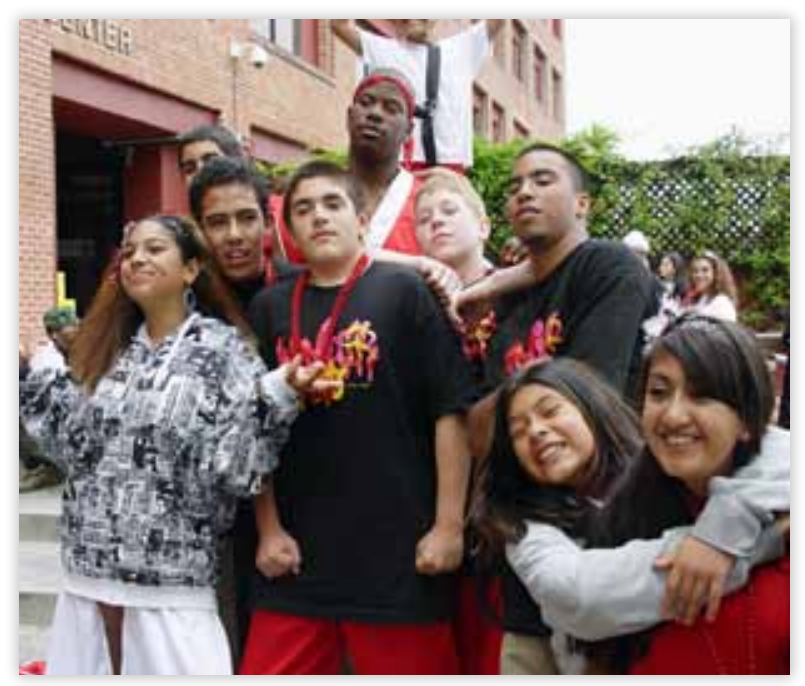




\section{References}

Arbreton, Amy J. A., and W. McClanahan. 2002. Targeted outreach: Boys and Girls Clubs of America’s approach to gang prevention and intervention. Philadelphia: Public/Private Ventures.

Diem, K. 1994. New Jersey leader training series. How to write a news release. New Brunswick, N.J.: Rutgers State University Press. Retrieved on December 23, 2006 from http://njaes.rutgers.edu/pubs/pdfs/4h/e148/351-356. pdf.

Halpern, R. 2005. Confronting the big lie: The need to reframe expectations of after-school programs. New York, N.Y.: Partnership for After School Education. Accessed from www.pasesetter.org/publicationResources/ Publicatons/PDF/halpern.pdf.

James-Burdumy, S., M. Dynarski, M. Moore, J. Deke, W. Mansfield, and C. Pistorino. 2005. When schools stay open late: The national evaluation of the 21st century community earning centers program. Final report: U.S. Department of Education, Institute of Educational Sciences, National Center for Education Evaluation and Regional Assistance. Retrieved on September 9, 2005 from http://www.mathematica-mpr.com/publications/ pdfs/21stfinal.pdf.

Junge, S., E. Conklin-Ginop, D. Cudaback, N. Feldman, W. Horikoshi, A. Cotter, et al. 1993. Summer and full-day curriculum manual. University of California Cooperative Extension Library, \#4-H910. (Available from Placer County Cooperative Extension.)

Junge, S., N. Feldman, R. Ingram, S. Maglallan, D. Metz, and D. Snell. 1986. 4-H after-school management and curriculum manual. University of California Cooperative Extension. (Out of print.)

Raley, R., J. Grossman, and K. Walker. 2005. Getting it right: Strategies for after-school success. Philadelphia: Public/ Private Ventures.

Rutgers Cooperative Extension: New Jersey Agricultural Experiment Station. 2001. How to write a news release. New Brunswick, N. J.: The State University of New Jersey.

Sonoma County Volunteer Center. 2002. Recruiting volunteers workshop: Discussion among agencies. Santa Rosa, Calif.

Todd, C. 1995. School-age childcare training manual. University of Illinois: Cooperative Extension Service.

\section{Inquiry and Experiential Learning}

The activities in this curriculum were designed around inquiry and experiential learning. Inquiry is a learner-centered approach in which individuals are problem solvers investigating questions through active engagement, observing and manipulating objects and phenomena, and acquiring or discovering knowledge. Experiential learning (EL) is a foundational educational strategy used in 4-H. In it, the learner has an experience phase of engagement in an activity, a reflection phase in which observations and reactions are shared and discussed, and an application phase in which new knowledge and skills are applied to real-life settings.

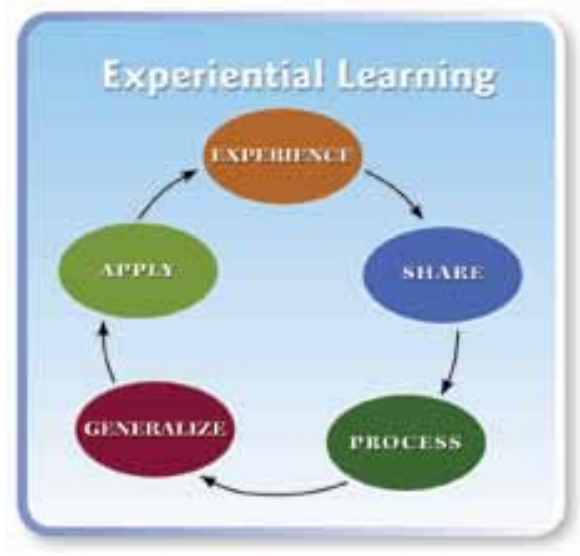
In 4-H, an EL model that uses a five-step learning cycle is most commonly used. These five steps-Experiencing, Sharing, Processing, Generalizing, and Application —are part of a recurring process that helps build learner understanding over time.

For more information on inquiry, EL, and the five-step learning cycle, please visit the University of California Science, Technology, and Environmental Literacy Workgroup’s Experiential Learning Web site, http://www.experientiallearning.ucdavis.edu/. 


\section{For More Information}

To order ANR products or download free publications, visit the ANR Communication Services online catalog at http://anrcatalog.ucanr. edu or phone 1-800-994-8849. You can also place orders by mail or FAX, or request a printed catalog of our products from

University of California

Agriculture and Natural Resources

Communication Services

1301 S. 46th Street

Building 478 - MC 3580

Richmond, California 94604-4600

Telephone: 1-800-994-8849 or 510-665-2195, FAX: 510-655-3427

e-mail inquiries: anrcatalog@ucanr.edu

An electronic copy of this publication can be found at the ANR

Communication Services Web site, http://anrcatalog.ucanr.edu. Publication 8433

ISBN-13: 978-1-60107-727-1

\footnotetext{
UC.

PEVIEWED $\odot 2012$ by The Regents of the University of California Agriculture and Natural Resources.

All rights reserved.
}

The University of California Division of Agriculture \& Natural Resources (ANR) prohibits discrimination against or harassment of any person participating in any of ANR's programs or activities on the basis of race, color, national origin, religion, sex, gender identity, pregnancy (which includes pregnancy, childbirth, and medical conditions related to pregnancy or childbirth), physical or mental disability, medical condition (cancer-related or genetic characteristics), genetic information (including family medical history), ancestry, marital status, age, sexual orientation, citizenship, or service in the uniformed services (as defined by the Uniformed Services Employment and Reemployment Rights Act

\section{Appendix}

Forms and informational booklets published by the California State 4-H Office are available free of charge at www.ca4h.org/Resources/Publications/. Look for the "Project Leader's Digest" for guidelines on setting up 4-H activities.

Many counties now offer or require online enrollment in 4-H programs. Contact your local UC Cooperative Extension County Office for information.

If your 4-H program is outside of California, please contact your state's 4-H office to obtain correct, current information.

The following materials in the Appendix support the hiring of staff, recruitment and enrollment of participants, and working with volunteers. Be sure to include clear job descriptions for adults, whether they are paid staff or volunteers. of 1994: service in the uniformed services includes membership, application for membership, performance of service, application for service, or obligation for service in the uniformed services) or any person in any of its programs or activities.

University policy also prohibits retaliation against any employee or person participating in any of ANR's programs or activities for bringing a complaint of discrimination or harassment pursuant to this policy. This policy is intended to be consistent with the provisions of applicable State and Federal laws.

Inquiries regarding the University's equal employment opportunity policies may be directed to Linda Marie Manton, Affirmative Action Contact, University of California, Davis, Agriculture and Natural Resources, One Shields Avenue, Davis, CA 95616, (530) 7520495. For information about ordering this publication, telephone 1-800-994-8849. For assistance in downloading this publication, telephone 530-754-3927.

To simplify information, trade names of products have been used. No endorsement of named or illustrated products is intended, nor is criticism implied of similar products that are not mentioned or illustrated.

This publication has been anonymously peer reviewed for technical accuracy by University of California scientists and other qualified professionals. This review process was managed by the ANR Associate Editor for Human and Community Development-Youth Development, Lynn Schmitt-McQuitty.

web-7/12-WJC/EZA

\section{Handouts}

- Parent handbook

- Recruitment postcards

- 4-H volunteer adult enrollment packet (download from www.ca4h.org/Join/Volunteer/)

- Volunteer job description form

- Appropriate roles for volunteers

- Interview questions

- 4-H Junior and teen leader planning and report form (download from www.ca4h.org/ Programs/Clubs/JuniorTeenLeaders/)

\section{Job Descriptions}

- Program Coordinator

- Site Director

- Lead Percussionist Drums Instructor

- Assistant Drum Instructor 


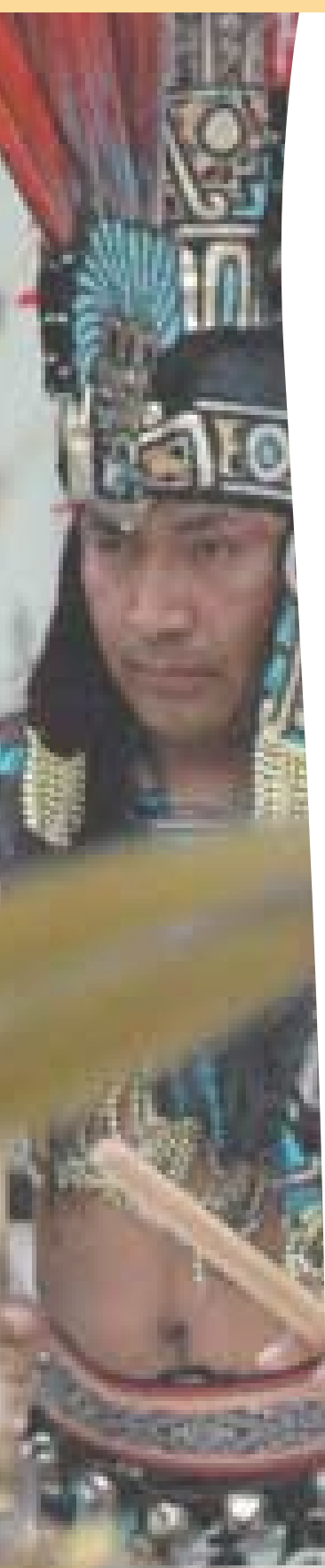

- Batteria Dance Instructor

- Assistant Batteria Instructor

- Food Demonstration and Snack Coordinator 


\section{PARENT HANDBOOK FOR 4-H BLOCO DRUM AND DANCE}

\section{Welcome to the 4-H after School Drum and Dance Program!}

The 4-H Bloco Drum and Dance Program is designed to provide after school activities targeted at Junior and High School Teens It will use drum and dance classes, healthy snacks and food demonstrations to promote healthy eating options for different types of exercise and appreciation of our diverse cultures within California

Parent support in our program is a key to success. This handbook includes program policies and ways that you can help support the program. Special thanks to our 4-H Bloco Advisory Committee for their input.

\section{The 4-H Bloco Drum and Dance Program Operates on the Following Principles:}

\section{Program Objectives}

- Provide an alternative after school activity for teens

* Provide enriching and educational activities that lead to greater community involvement

* Provide healthy physical activities

- Create positive adult/child interaction and communication

* Introduce teens to a curriculum of dance and drumming that increase their physical activity

* Utilize 4-H delivery methodologies through experiential education "handson-learning" and "learn-by-doing."

* Recognize and utilize volunteer talent

\section{Location}

* Windsor Middle School (Drumming)

900 Brooks Road South

Windsor, California 95492

* Windsor High School (Dancing)

8695 Windsor Road

Windsor, California 95452

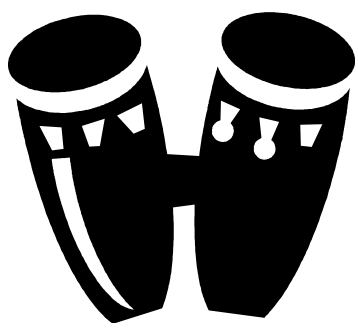

Hours of Operation

3:45 p.m.-5:15 p.m. (Drumming)

4:00-p.m.-5:30p.m. (Dancing)

Contacts:

(List contacts here)

\section{The 4-H Bloco Advisory Committee}

This Committee oversees the program and is made up of volunteers from agencies, community groups, youth programs, parents and teens. If you would like to be part of the Advisory committee we invite you to join. They are various 
committees within the Advisory group who could you your assistance. Please join us and share your input.

\section{Enrollment Procedure}

Enrollment is open to any teen until we reach maximum capacity. Each teen should fill out a 4-H enrollment packet that includes the medical emergency form, Code of Conduct, the Windsor school release for and pay the registration fees. All forms and fees should be given to the Site Director.

\section{Days of Operation}

The program will operate on Mondays and Thursdays. Drum Classes are from 3:45 pm to 5:15 pm at the Windsor Middle School. Dance classes are at the Windsor High School from 4:00 p.m to 5:30 pm. Once a month both classes will meet at the Middle School for joint classes. (See instructors for dates and times of combined practice.

* On days when school is closed, for in-service or teachers conferences or holidays, the program will not be available.

* The program closes at 5:15 p.m. for drum classes and 5:30 p.m. for dance classes. Parents/guardians must arrange for rides promptly at the close of the classes. If a teen is leaving the grounds on a bike or other means, a signed note by the parent/guardian must be on file. Students who are left late on a consistent basis may be subject to removal from the program.

\section{Fees and Related Policies}

The 4-H Bloco Drum and Dance Program is administered as a non-profit organization. It is our intent to provide the highest quality service at the lowest cost to parents. The program is supported by parent fees, dinners, sponsors, fund raising and grant writing:

1. The program is 30 weeks in length. Fees are $\$ 60$ a semester either drum and dance classes

2. A non-refundable registration fee is due at the time of enrollment in the program. The completed enrollment forms must accompany fees.

3. Some partial scholarships are available. Apply through the Site Director.

4. Fees are due in advance of each semester.

5. Failure to pay fees is cause for removal from the program.

6. No refunds will be made for illness or absences.

7. Parents will be notified at least two weeks in advance, for any rate increases.

\section{Medical and Health Information}

The 4-H Bloco Drum and Dance Program is sensitive to the health and physical needs of teens; therefore the following policies have been adopted.

1. It is the parent's responsibility to keep the program informed of any change in teen's emergency medical or physical conditions.

2. Medical release forms are to be onsite during all program activities as well as when transporting to another location for drum and dance programs.

3. In all cases of injury or illness, attempts will be make to contact parents immediately and involve them in the decision regarding treatment. 
4. In case of serious illness or injury, the staff will follow parental instructions on the 4-H Medical Treatment form whenever possible; however, in all cases staff will deal with serious emergencies in the most expeditious way possible.

5. The program cannot transport children to out of the area physicians, so if staff is unable to locate the parents or an

6. Emergency contact, staff will secure appropriate treatment at the nearest medical facility. If a major injury or illness is involved the child will be transported by ambulance to a designated site and/our physician. Medical release forms are to be with the volunteer/staff in charge at all times.

\section{Site Emergency}

In the event of an emergency or natural disaster the following procedure will be in effect:

1. Teens will remain at the site until they can be picked up by the parent or other authorized person.

2. In the event of a site evacuation, teens will be taken to a local emergency center. The location will be posted on the Student Advisor's door. Efforts will be made to contact parents should evacuation be necessary.

3. 4-H Bloco Staff will remain with the teens until they are picked up by the parent or authorized person.

\section{Discipline}

Discipline is based on the dignity of each teen. Any forms of discipline that impairs the student's self respect will be avoided. The instructor's role is one of a strong"leader and role model, setting an example in which students can grow towards self-discipline and self-direction. A dynamic program that is adapted to the needs and interest of the teens keeps discipline problems to the minimum.

The 4-H Code-of-Conduct must be signed by the teens and their parents and /or legal guardian. This outlines the expected behavior of teens participating in the program. Please be sure to read it before signing.

When inappropriate or unacceptable behavior is exhibited, staff will confer with the Windsor School Student Advisors and discuss positive ways to change behavior. Discussion with parents/guardians will also occur if negative behavior continues.

\section{Nutrition}

The 4-H Bloco Drum and Dance Program will provide a healthy snack before each rehearsal if funding allows. These snacks will be nutritious and contain a serving from at least two of the Food Groups as outline by the United States Department of Agriculture in "My Pyramid" food guidance system.

\section{Transportation}

1. Transportation to and from the program is the responsibility of the parent.

2. Any trip out of the County of Sonoma, the accompanying volunteer or staff must have a medical treatment form, for each member with original signatures form parents and/or guardian in their possession.

3. When transportation is needed for field trips, all drivers must follow California driving regulations and comply with the following standards: 
* A valid California driver's license.

*ehicle insurance as required by the State of California

* Use a safe operating vehicle.

Seat belts for each passenger as the law requires.

\section{Sign-in Sheets}

Sign-in Sheets must be kept on all teens who attend the program. Each teen is required to sign-in each practice day. In the case of teens leaving the program by walking, riding a bike, or other means, a signed note by the parent must be on file which gives specific instructions and time for releasing the teen.

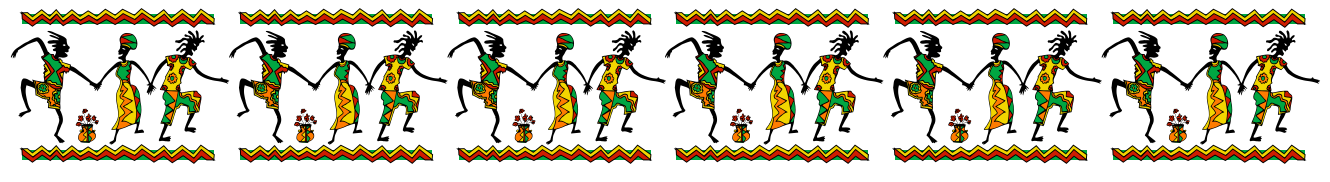

The University of California Division of Agriculture \& Natural Resources (ANR) prohibits discrimination against or harassment of any person participating in any of ANR's programs or activities on the basis of race, color, national origin, religion, sex, gender identity, pregnancy (which includes pregnancy, childbirth, and medical conditions related to pregnancy or childbirth), physical or mental disability, medical condition (cancer-related or genetic characteristics), genetic information (including family medical history), ancestry, marital status, age, sexual orientation, citizenship, or service in the uniformed services (as defined by the Uniformed Services Employment and Reemployment Rights Act of 1994: service in the uniformed services includes membership, application for membership, performance of service, application for service, or obligation for service in the uniformed services) or any person in any of its programs or activities.

University policy also prohibits retaliation against any employee or person participating in any of ANR's programs or activities for bringing a complaint of discrimination or harassment pursuant to this policy. This policy is intended to be consistent with the provisions of applicable State and Federal laws.

Inquiries regarding the University's equal employment opportunity policies may be directed to Linda Marie Manton, Affirmative Action Contact, University of California, Davis, Agriculture and Natural Resources, One Shields Avenue, Davis, CA 95616, (530) 752-0495. For information about ordering this publication, telephone 1-800-994-8849. For assistance in downloading this publication, telephone 530-754-3927. 


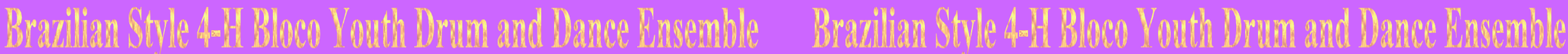
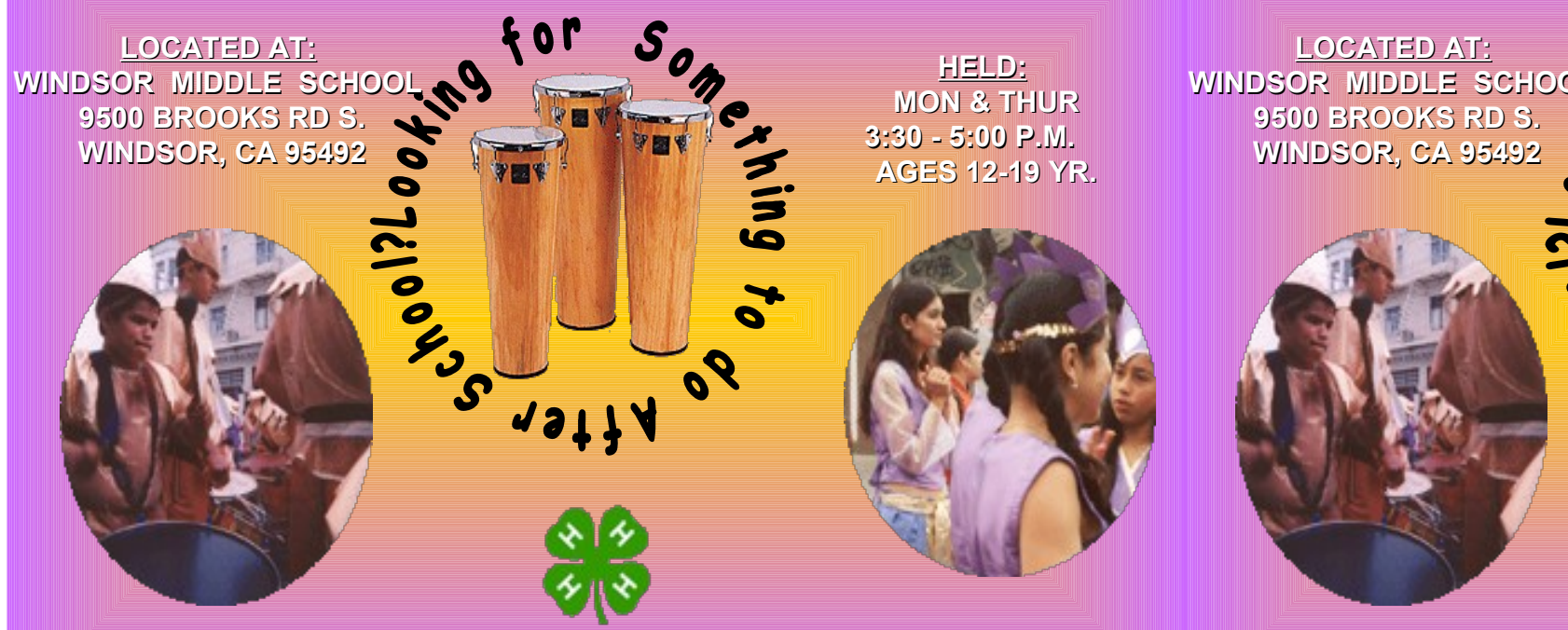

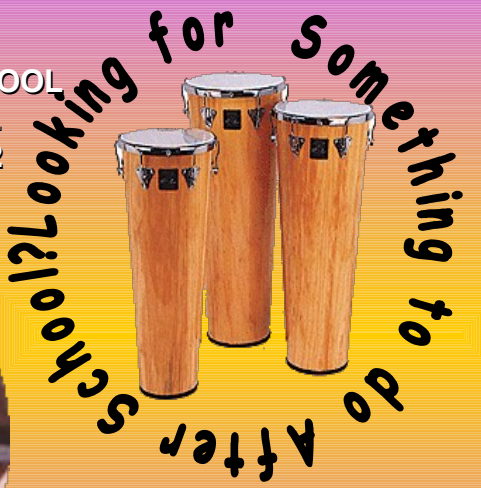

$(4)$

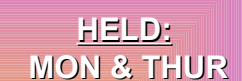

$3,30-5,00$ P. P. P.

AGES $12-19 Y R$.

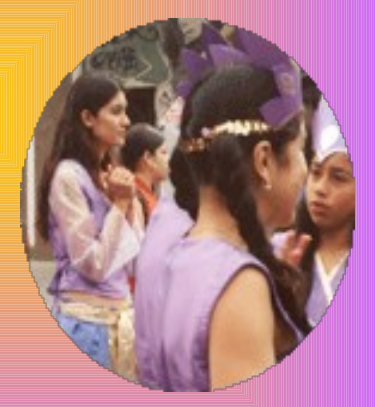

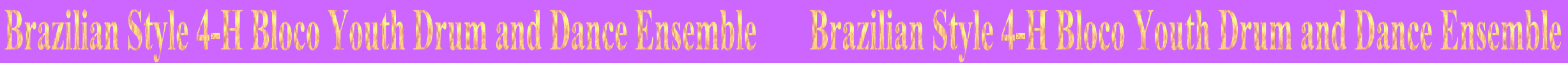
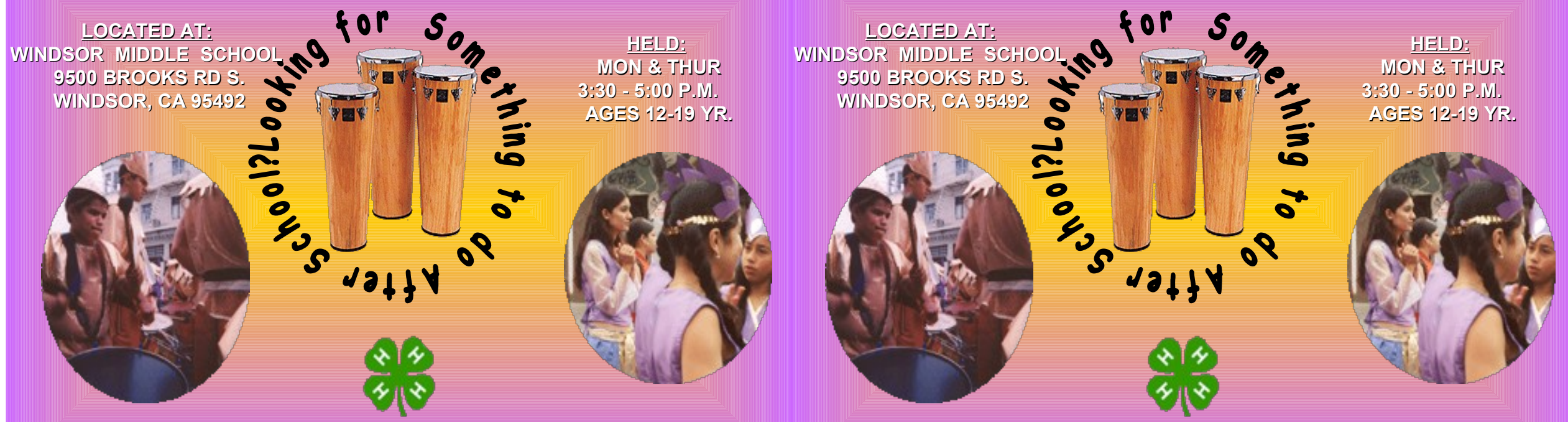

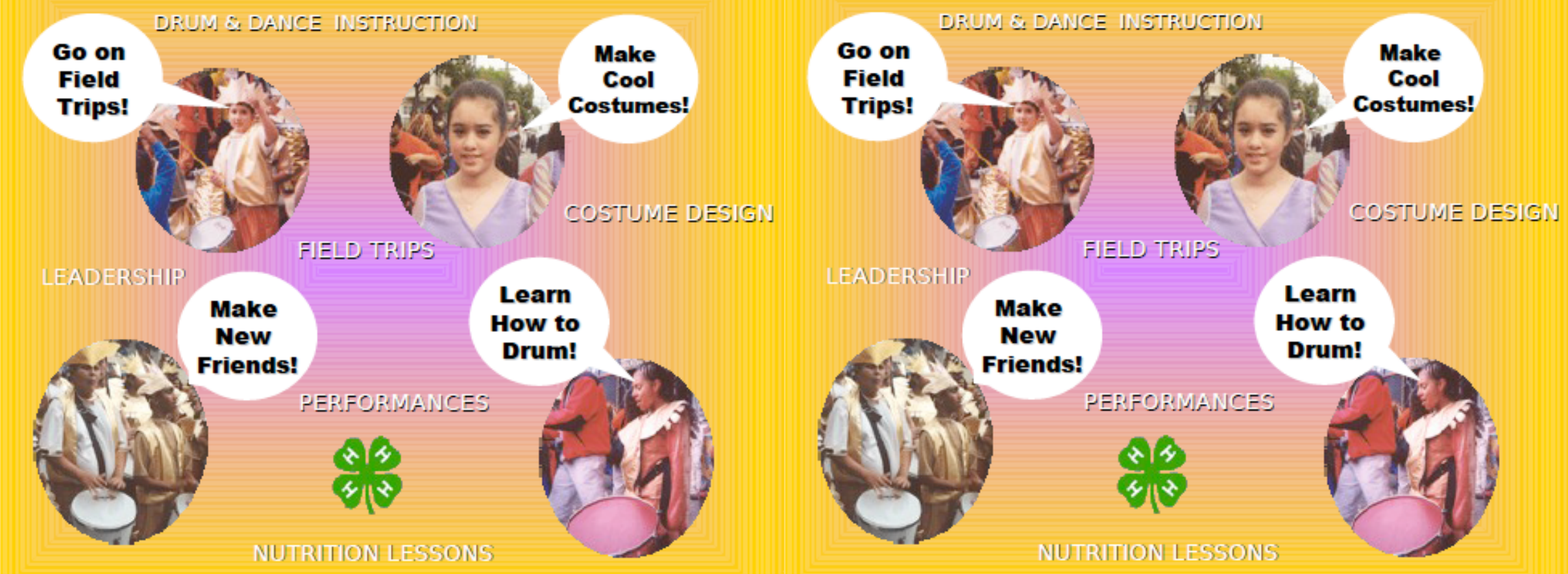

Join 4-H Bloco Youth Drum and Dance Ensemble!

Join 4-H Bloco Youth Drum and Dance Ensemble!
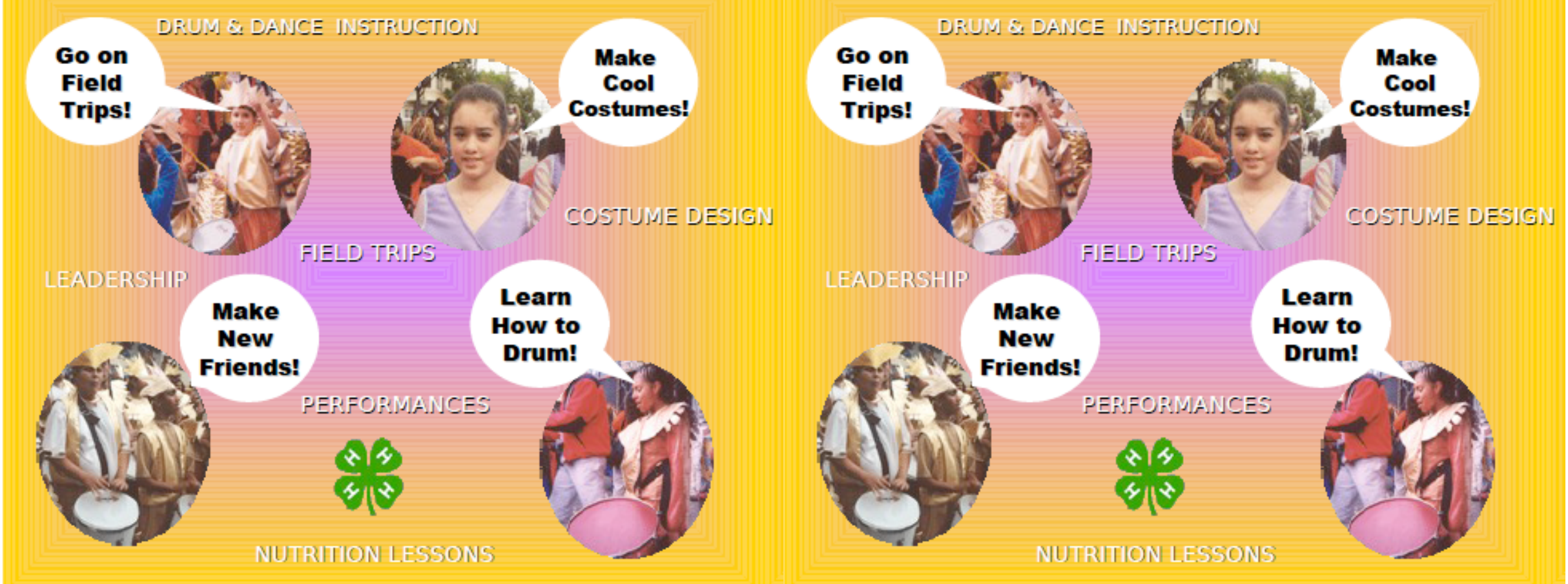


\section{VOLUNTEER JOB DESCRIPTION}

Job Title:

Supervisor:

Job Description:

Commitment:

Qualifications:

Training:

Benefits:

Value to Agency: 


\section{APPROPRIATE ROLES FOR VOLUNTEERS}

\begin{tabular}{|c|c|c|c|}
\hline Task & Volunteer name & $\begin{array}{c}\text { Phone number, } \\
\text { address }\end{array}$ & $\begin{array}{l}\text { Comments for the next } \\
\text { volunteer. } \\
\text { (Was it successful? What } \\
\text { worked? What should be } \\
\text { done differently?) }\end{array}$ \\
\hline $\begin{array}{l}\text { 1. Set up food } \\
\text { demonstrations. }\end{array}$ & & & \\
\hline $\begin{array}{l}\text { 2. Work as an } \\
\text { assistant. }\end{array}$ & & & \\
\hline $\begin{array}{l}\text { 3. Put together a } \\
\text { volunteer } \\
\text { handbook. }\end{array}$ & & & \\
\hline $\begin{array}{l}\text { 4. Coordinate a } \\
\text { fundraising event. }\end{array}$ & & & \\
\hline $\begin{array}{l}\text { 5. Type reports for } \\
\text { volunteer } \\
\text { managers or } \\
\text { other staff. } \\
\end{array}$ & & & \\
\hline $\begin{array}{l}\text { 6. Design a web } \\
\text { page. }\end{array}$ & & & \\
\hline $\begin{array}{l}\text { 7. Design and } \\
\text { maintain a } \\
\text { database. }\end{array}$ & & & \\
\hline $\begin{array}{l}\text { 8. Be in charge of } \\
\text { healthy snacks. }\end{array}$ & & & \\
\hline 9. Process checks. & & & \\
\hline $\begin{array}{l}\text { 10. Evaluate } \\
\text { volunteer } \\
\text { program. }\end{array}$ & & & \\
\hline $\begin{array}{l}\text { 11. Do the publicity } \\
\text { for an upcoming } \\
\text { volunteer training. }\end{array}$ & & & \\
\hline $\begin{array}{l}\text { 12. Conduct the } \\
\text { volunteer } \\
\text { orientation. }\end{array}$ & & & \\
\hline
\end{tabular}

Adapted from the Volunteer Center of Sonoma County. 


\section{SUGGESTED INTERVIEW QUESTIONS FOR INSTRUCTOR JOB APPLICANTS}

Make Hiring a Key Aspect of Ensuring Program Quality

According to Integrating Physical Activity into the Complete School Day (NASPE), school children are encouraged to be physically active for at least 60 minutes and up to several hours per day. During the school day, children and youth need a break from sedentary activities in the classroom. Physical activity breaks meet this need and can increase individuals' daily physical activity levels!

Schools have reduced physical activity for children in recent years. This trend is largely due to the conversion of physical education time into time devoted to other subjects in preparation for standardized testing. After-school programs provide an excellent way to increase physical activity throughout the day without taking away valuable time from school requirements. An increase in physical activity promotes good health and well being for participating teens.

\section{Suggested Job Interview Questions for Prospective Drum and Dance Instructors}

1. What do you believe are the characteristics of an effective drum/dance teacher?

2. What is an effective drum/dance program?

3. What do you want your students to learn in the program?

4. What are the "appropriate practices" in drum/dance?

5. How do you assess student skills?

6. How do you ensure the "safety and well-being" of all students?

7. How would you accommodate students with a variety of special needs?

8. What are your plans for professional involvement and self-improvement?

9. Would you be willing to attend in-service training on your own time?

10. Give an example of how you have been cooperative and flexible in a professional work environment.

11. Give an example of how you have been a part of a decision making process.

12. How do you think drum/dance can contribute to a total after-school curriculum?

13. Do you have any additional information you would like to share with us?.

\section{Reference}

National Association for Sports and Physical Education. 2009. Integrating physical activity into the complete school day. Retrieved December 14, 2009, from www.aahperd.org/naspe/publications/teachingTools/upload/PA-During-School-Day.pdf. 


\section{4-H BLOCO DRUM AND DANCE PROGRAM JOB DESCRIPTION: PROGRAM COORDINATOR}

The 4-H Bloco Drum and Dance Program is modeled after the Loco Bloco Program in the Mission District of San Francisco. The program has been structured to engage youth of many nationalities and ethnic backgrounds to share the love of music and dance while performing drum and dance ensemble events. A nutrition component is also included to increase participants' knowledge and teach them to make healthy food choices. Exercise through drum and dance is an additional focus.

\section{Job Description}

Under the supervision of the 4-H Youth Development Advisor, this position is designed to work with the Advisory Committee members to conduct fundraising, plan long-term goals, and oversee program sites; also oversees the enrollment process, employee timesheets, performance dates, and transportation to major events.

\section{Example of Duties}

This individual will serve as a link between the UCCE Office and the four schools from which students will be recruited. He/She will work with the Fundraising Chair to develop funding and work with the Advisory Committee to promote the program. This position will be the link with the San Francisco Loco Bloco (Carnaval) and supervise arrangements that enable the program's participating youth to take part in this event. This person will also work with the Site Director to conduct parent meetings and serve as the contact with other groups wishing to schedule performances.

\section{Employment Standards}

Requirements: Possession of a valid California Drivers License; fingerprint clearance; and 4-H Leader Orientation and enrollment procedure. Complete school orientation of school site and school policies if deemed necessary by the school Principal.

Knowledge of: Developmental needs of junior high and high school teens. Understanding the principles and practices of working with teens. Understanding the workings of community groups. Ability to share knowledge with others in a teamwork environment.

Experience and Education: High school diploma or GED. Enjoy working with teens. Possess people skills.

Salary: Up to $\$ 2000$ for the year.

Time: Hours are flexible and should be used as needed. 


\section{4-H BLOCO DRUM AND DANCE PROGRAM JOB DESCRIPTION: SITE DIRECTOR}

The 4-H Bloco Drum and Dance Program is modeled after the Loco Bloco Program in the Mission District of San Francisco. The program has been structured to engage youth of many nationalities and ethnic backgrounds to share the love of music and dance while performing drum and dance ensemble events. A nutrition component is also included to increase participants' knowledge and teach them to make healthy food choices. Exercise through drum and dance is an additional focus.

\section{Duties Include}

* Design the class schedule.

* Ensure that all students complete the 4-H enrollment process for liability and insurance purposes as well as the Code-of-Conduct, which outlines behavior requirements.

* Collect fees for program participation and turn them in to the bookkeeper.

* Ensure that dance and drum participants sign in at each meeting. Sign-in list should be turned in to the UCCE office for record keeping.

* Coordinate site work, including contact with school personnel.

* Secure instructors and volunteers in the community to lead each class. Clear staff selection with the Advisory Committee.

- Acquire parent/committee volunteers (examples of volunteer jobs might be transportation or help with sign-in, etc.).

- Coordinate parent meetings and request assistance from parents where needed.

* Organize and coordinate transportation for special events and activities.

* Participate on the Advisory Committee and provide regular progress reports.

Help with promotion, recruitment, and publicity for the program.

\section{Budget}

* Requests for expenses must be submitted to the funding agent (UC Regents) 10 working days in advance. Expenses may be submitted in either of two ways: (1) A request for reimbursement that includes submittal of original receipts with the date and totals clearly readable; or (2) Purchase Order.

* Ensure that timesheets from drum and dance instructors are accurate and signed by the instructors. Submit invoices to the Sonoma County UCCE Office.

* Items or events in need of funding other than what was allotted in the grant will need to be brought to the Advisory Committee for approval prior to making any purchases.

\section{Relationship to 4-H Bloco Drum and Dance Advisory Committee}

* The Site Director is hired by and responsible to the Advisory Committee, which sets the program's direction and develops plans that are implemented by the site staff.

* Performances dates should be approved by the Advisory Committee prior to being accepted or booked.

Salary: $\$ 8000$ for 36 weeks and all performances.

Total hours per work week: $10-20$ 


\section{4-H BLOCO DRUM AND DANCE PROGRAM JOB DESCRIPTION: \\ LEAD PERCUSSIONIST (DRUMS)}

The 4-H Bloco Drum and Dance Program is modeled after the Loco Bloco Program in the Mission District of San Francisco. The program has been structured to engage youth of many nationalities and ethnic backgrounds to share the love of music and dance while performing drum and dance ensemble events. A nutrition component is also included to increase participants knowledge and teach them to make healthy food choices. Exercise through drum and dance is an additional focus.

\section{Job Description}

Under supervision of the Site Director, implement the two-to-three-times-perweek program of instruction of the after-school Bloco Drum and Dance Program, and do related work as required.

\section{Example of Duties}

Lead the percussionist section of the program by teaching participants Latin American drum rhythms. Assist in organization, planning, and implementation of the educational recreational activities of the program, which are subject to the approval of the Site Director and Advisory Committee.

Serve as a liaison with the San Francisco Bloco Artists and learn rhythms for Loco Bloco Carnaval. This may include attending classes in San Francisco at the main Loco Bloco headquarters if the instructor is not a member of San Francisco Loco Bloco. Work with Assistant Drum Instructor to teach students Loco Bloco rhythms so they will be able to participate with other youth groups throughout California at Carnaval in May. Work with parent volunteers to strengthen the program. Work with Batteria (Dance) Instructor on choreography for the group.

\section{Employment Standards}

Requirements: Possession of a valid California Drivers License; fingerprint clearance; 4-H Leader Orientation and enrollment procedure. Complete school orientation of school site and school policies, if deemed necessary by the school Principal. Experience in drumming.

Knowledge of: Developmental needs of junior high and high school teens. Understand the principles and practices of working with teens. Understand rhythms and drumming techniques. Ability to share knowledge with and work with others in a teamwork environment.

Experience and Education: High school graduation or GED. Experience in teaching and performing drum rhythms. Enjoy working with teens. Possess people skills.

Salary: $\$ 150$ weekly for 36 weeks plus performances.

Time: Mondays, Wednesdays, and Thursdays, 3:45 pm to 5:45 pm. 


\section{4-H BLOCO DRUM AND DANCE PROGRAM JOB DESCRIPTION: \\ ASSISTANT DRUM INSTRUCTOR}

The 4-H Bloco Drum and Dance Program is modeled after the Loco Bloco Program in the Mission District of San Francisco. The program has been structured to engage youth of many nationalities and ethnic backgrounds to share the love of music and dance while performing drum and dance ensemble events. A nutrition component is also included to increase participants knowledge and teach them to make healthy food choices. Exercise through drum and dance is an additional focus.

\section{Job Description}

Under supervision of the Site Director, implement the two-to-three-times-perweek program of instruction of the after-school Bloco Drum and Dance Program, and do related work as required.

\section{Example of Duties}

Assist in leading the percussionist section of the program by teaching participants Latin American drum rhythms. Assist in organization, planning, and implementation of the educational recreational activities of the program, which are subject to the approval of the Site Director and Advisory Committee.

Work with Lead Percussionist to learn Loco Bloco drum rhythms. Teach students Latin Drum instruction for local performances. Work with Lead Percussionist to teach students Loco Bloco rhythms so they will be able to participate with other youth groups throughout California in Carnaval and other performances. Work with parent volunteers and teen leaders to strengthen the program.

\section{Employment Standards}

Requirements: Possession of a valid California Drivers License; fingerprint clearance; 4-H Leader Orientation and enrollment procedure. Complete school orientation of school site and school policies, if deemed necessary by the school Principal. Experience in drumming.

Knowledge of: Developmental needs of junior high and high school teens. Understand the principles and practices of working with teens. Understand rhythms and drumming techniques. Ability to share knowledge with and work with others in a teamwork environment.

Experience and Education: High school graduation or GED. Experience in teaching and performing drum rhythms. Enjoy working with teens. Possess people skills.

Salary: $\$ 100$ bi-weekly for 36 weeks.

Time: Mondays, Wednesdays, and Thursdays, 3:45 pm to 5:45 pm. 


\section{4-H BLOCO DRUM AND DANCE PROGRAM JOB DESCRIPTION: \\ BATTERIA (DANCE) INSTRUCTOR}

The 4-H Bloco Drum and Dance Program is modeled after the Loco Bloco Program in the Mission District of San Francisco. The program has been structured to engage youth of many nationalities and ethnic backgrounds to share the love of music and dance while performing drum and dance ensemble events. A nutrition component is also included to increase participants knowledge and teach them to make healthy food choices. Exercise through drum and dance is an additional focus.

\section{Job Description}

Under supervision of the Site Director, implement the once-a-week program of instruction for the after-school 4-H Bloco Drum and Dance Program, and do related work as required.

\section{Example of Duties}

Attend after-school dance sessions weekly. Lead the dance section of the program, which teaches participants Latin American traditional dance. Assist in organization, planning and implementation of the educational recreational activities of the program, which are subject to the approval of the Site Director and Advisory Committee.

Attend Loco Bloco lessons to learn dance routines for Carnaval. Work with Lead Percussionist (Drum) Instructor to learn Loco Bloco drum rhythms and how dance steps work with drums. Teach students Latin Dance for local performances. Work with parent volunteers and teen leaders to strengthen the program.

\section{Employment Standards}

Requirements: Possession of a valid California Drivers License; fingerprint clearance; 4-H Leader Orientation and enrollment procedure. Complete school orientation of school site and school policies, if deemed necessary by the school Principal. Experience in Dance.

Knowledge of: Developmental needs of junior high and high school teens. Understand the principles and practices of working with teens. Understand rhythms and drumming techniques. Ability to share knowledge with and work with others in a teamwork environment.

Experience and Education: High school diploma or GED. Brazilian dance background desirable. Previous teaching experience in dance highly recommended. Enjoy working with teens. Possess people skills.

Salary: Range of up to $\$ 125$ weekly, depending on the time commitment.

Length of term: 36 weeks.

Time: Tuesdays. Wednesdays, and Thursdays, $3: 45 \mathrm{pm}$ to $5: 45 \mathrm{pm}$. 


\section{4-H BLOCO DRUM AND DANCE PROGRAM JOB DESCRIPTION: \\ ASSISTANT BATTERIA (DANCE) INSTRUCTOR}

The 4-H Bloco Drum and Dance Program is modeled after the Loco Bloco Program in the Mission District of San Francisco. The program has been structured to engage youth of many nationalities and ethnic backgrounds to share the love of music and dance while performing drum and dance ensemble events. A nutrition component is also included to increase participants' knowledge and teach them to make healthy food choices. Exercise through drum and dance is an additional focus.

\section{Job Description}

Under supervision of the Site Director, implement the once-a-week program of instruction for the after-school 4-H Bloco Drum and Dance Program, and do related work as required.

\section{Example of Duties}

Attend after-school dance sessions weekly. Lead the dance section of the program, which teaches participants Latin American traditional dance. Assist in organization, planning and implementation of the educational recreational activities of the program, which are subject to the approval of the Site Director and Advisory Committee.

Work with Batteria (Dance) Instructor to learn Loco Bloco dance steps. Teach students Latin Dance for local performances. Work with parent volunteers and teen leaders to strengthen the program.

\section{Employment Standards}

Requirements: Possession of a valid California Drivers License; fingerprint clearance; 4-H Leader Orientation and enrollment procedure. Complete school orientation of school site and school policies, if deemed necessary by the school Principal. Experience in Dance.

Knowledge of: Developmental needs of junior high and high school teens. Understand the principles and practices of working with teens. Understand rhythms and drumming techniques. Ability to share knowledge with and work with others in a teamwork environment.

Experience and Education: High school diploma or GED. Brazilian dance background desirable. Previous teaching experience in dance highly recommended. Enjoy working with teens. Possess people skills.

Salary: $\$ 100$ weekly for 36 weeks.

Time: Mondays, Wednesdays, and Thursdays, 3:45 pm to 5:45 pm. 
The 4-H Bloco Drum and Dance Program is modeled after the Loco Bloco Program in the Mission District of San Francisco. The program has been structured to engage youth of many nationalities and ethnic backgrounds to share the love of music and dance while performing drum and dance ensemble events. A nutrition component is also included to increase participants' knowledge and teach them to make healthy food choices. Exercise through drum and dance is an additional focus.

\section{Job Description}

Under supervision of the Site Director, set up a bi-weekly snack schedule based on the healthy snack curriculum designed by the program. Also present a healthy snack food demonstration and tasting once a month and present nutrition information.

\section{Example of Duties}

Plan, prepare, and serve the snacks before practice, twice a week. Assist in organization, planning, and implementation of the educational recreational activities of the program, as they relate to the nutrition component. Plan food demonstrations, tastings, and educational information. All program sections are subject to the approval of the Site Director and Advisory Committee. Work with parent volunteers and teen leaders to strengthen the program by involving them in food preparation for snacks and food demonstrations.

\section{Employment Standards}

Requirements: Possession of a valid California Drivers License; fingerprint clearance; 4-H Leader Orientation and enrollment procedure. Complete school orientation of school site and school policies, if deemed necessary by the school Principal.

Knowledge of: Developmental needs of junior high and high school teens. Understand the principles and practices of working with teens. Understand rhythms and drumming techniques. Ability to share knowledge with and work with others in a teamwork environment.

Experience and Education: High school diploma or GED. Nutrition education desirable but not required. Enjoy working with teens. Possess people skills.

Salary: \$50 a week for 36 weeks. (also an excellent volunteer position).

Time: Tuesdays, Wednesdays, and Thursdays. Hours very. Snack preparation is completed before class. Food demonstrations are presented during the first 15 minutes of selected classes. Average 8 hours a week. 